\title{
Synthesis, Evaluation and in silico studies of 1,8-Naphthyridine derivatives against antimicrobial activity
}

\author{
Sakshi Sachdeva ${ }^{a}$, Sonam Bhatia, ${ }^{a}$ Amit Mittal ${ }^{a}$, Manish Sinha ${ }^{b}$ \\ ${ }^{a}$ School of Pharmaceutical Sciences, Lovely Professional University, Phagwara-144411, India. \\ ${ }^{\mathrm{b}}$ Department of Pharmaceutical Chemistry, ASBASJS Memorial College of Pharmacy, Bela, Punjab, India.
}

\section{ARTICLE INFO \\ Article history: \\ Received on: 17/03/2015 \\ Revised on: 12/04/2015 \\ Accepted on: 03/05/2015 \\ Available online: 27/07/2015}

Key words:

1,8-Naphthyridine, Nalidixic

acid, Antimicrobial activity,

Ames mutagenicity,

Molecular docking, QSTR,

Structure based design

\begin{abstract}
In present studies a series of novel 1,8-Naphthyridine derivatives (3a-3f) have been synthesized using nalidixic acid as a starting material. The structures of the compounds were supported by FT-IR, ${ }^{1} \mathrm{H}$ NMR and Mass spectral data. All the synthesized compounds have been evaluated in vitro for their antibacterial activities against several strains of microbes using agar dilution method. The synthesized compounds had moderate to good antibacterial activity. Molecular docking studies reveal that 1,8-Naphthyridine scaffold shared structural complimentary with DNA Gyrase B. Further, TOPKAT analysis on Ames mutagenicity model had shown that this class of compounds have least probability of showing toxicity on experimental animal models.
\end{abstract}

\section{INTRODUCTION}

Microbes are causative agents for various types of diseases like pneumonia, amoebiasis, typhoid, malaria, common cold, cough and other infections (Black J.G., 1993). Infectious diseases are the major health problem in the third world countries. These diseases are controlled with various drugs from synthetic to natural origin. Antimicrobial agents are the drugs, or substances that kill or slow the growth of microbes. They include antibacterial agents, anti quorum sensing agents, antiviral agents, antifungal agents and antiparasitic agents (Pelczar, 2005; Singh et al., 2014). Despite the availability of large number of antibiotics for clinical use, the emergence of antibiotic resistance in recent years against Gram-positive and Gram-negative bacterial and fungal strains constitutes an urgent need for the discovery of new class of antimicrobial agents (Perez et al., 2014; (Narasimhan et al., 2009; Arora et al., 2015). The increase in bacterial resistance has attracted considerable interest in the discovery and development of new classes of antibacterial agents (Aarons, 1997).

* Corresponding Author

Email: amit.13145@lpu.co.in
In order to overcome this rapid development of drug resistance, new agents should preferably consist of chemical characteristics that differ from those of existing agents. In drug designing programs an essential component of the search for new leads is the synthesis of molecules, which are novel yet resemble known biologically active molecules by virtue of the presence of critical structural features (Andriote, 1999; Silverman, 1992; Thompson, 1996). According to WHO report 2014, high rates of resistance have been observed in bacteria that cause common health-care associated and community-acquired infections (e.g. urinary tract infection, pneumonia) in all WHO regions. Globally, $3.6 \%$ of new TB cases and $20.2 \%$ of previously treated cases are estimated to have multidrug-resistant TB (MDR-TB), with much higher rates in eastern Europe and central Asia. This shows us the research on new compounds against these pathogens is needed (http://www.cdc.gov/drugresistance/threat-report-2013/).

Hence, there will always be a vital need to discover new chemotherapeutic agents to avert the emergence of resistance and ideally shorten the duration of therapy. Modification of the stabilized drug is another choice for novel drug discovery because the pharmacokinetics and pharmacodynamics of these drugs are well known. 1,8-Naphthyridine derivatives are reported to possess 
wide range of biological activities like $\mathrm{A}_{2 \mathrm{~A}}$ adenosine receptor ligands (Manera, C. et al 2005), $\mathrm{A}_{1}$ adenosine antagonists (Ferrarini et al., 2004), antimycobacterial (Ferrarini et al., 1998), anti-inflammatory (Dianzani et al., 2006), Cannabinoid receptor ligands (Ferrrarini et al., 2004), antibacterial activity (Lv et al., 2012). 1,8-Naphthyridine nucleus is found in nalidixic acid, which belong to antibacterial compounds called as quinolones. The quinolones are well established antibacterial agents which act as DNA gyrase inhibitors (Smith et al., 1986). Nalidixic acid and its various derivatives are found to possess antibacterial and antifungal activity (Gaurav et al., 2006). In the present study, we have made out our efforts to systhesize nalidixic acid derivatives which are modified at terminal carboxylic acid end. These compounds have shown better biological activity in comparison to nalidixic acid and in silico analysis of these modified structural motifs of nalidixic acid displayed better binding affinity with DNA Gyrase B enzyme (GyrB).

\section{MATERIAL AND METHODS}

\section{Experimental}

The chemicals employed for the synthetic work i.e. nalidixic acid was purchased from Hi-media and other chemicals i.e methanol, thionylchloride and various amines were purchased from Merck India and Spectrochem. The pre-coated thin layer chromatography (TLC) plates (Merck 60 F254) was used to monitor the reaction. Solvent systems used for developing the chromatogram was chloroform: methanol (9:1). Detection of the TLC spots of the components was made by the treatment of iodine vapours or by UV light. The identification and characterization of the compounds were carried out by determining melting point, FTIR, ${ }^{1} \mathrm{H}$ NMR ( ${ }^{1} \mathrm{H}$ Nuclear magnetic resonance), and Mass spectroscopy. Melting points were determined in open capillaries on sonar melting point apparatus and are uncorrected. All IR spectra were recorded on an FT-IR Perkin-Elmer spectrometer (4000-400 $\mathrm{cm}^{-1}$ ) using $\mathrm{KBr}$ pellets technique. ${ }^{1} \mathrm{H}$ NMR spectras were recorded on Bruker Avance II 400 NMR spectrometer (400 $\mathrm{MHz}$ ) in appropriate solvent. Chemical shifts were recorded in parts per million ( $\mathrm{ppm}$ ) downfield from tetramethylsilane. Mass spectras were run on micromas Q-T of micro spectrometer at SAIF Panjab University, Chandigarh.

\section{Preparation of nalidixic acid ester via nalidixoyl chloride from nalidixic acid}

$1 \mathrm{gm}$ of pure nalidixic acid was accurately weighed into a $250 \mathrm{ml}$ dry, clean, round bottom flask and $6 \mathrm{ml}$ of thionyl chloride was added and closed in fuming cupboard chamber. The flask was kept aside for $15 \mathrm{~min}$. Later $6 \mathrm{ml}$ of methanol was added to the solution in the round bottom flask drop by drop and mixed thoroughly after each addition. The Nalidixoyl chloride formed, in situ, by the addition of thionyl chloride to nalidixic acid reacted with methanol and was kept for refluxing. After completion of reaction nalidixic acid ester was isolated.

\section{General procedure for synthesis of derivatives (3a-3f)}

A mixture of $1 \mathrm{mmol}$ of nalidixic ester 2 and $10 \mathrm{mmol}$ of appropriate amines viz. (1) pyrrolidine, (2) methylamine, (3) 2,4dimethylaniline, (4) morpholine (5) piperidine, and (6) dimethylamine was heated at $120-160{ }^{\circ} \mathrm{C}$ for $60-70 \mathrm{~h}$. After cooling, the reaction mixture was treated with diethyl ether to give a solid residue which was collected by filteration and purified by recrystallization to obtained $3 \mathrm{a}-3 \mathrm{f}$.

\section{Analytical data \\ 1-Ethyl-7-methyl-3-(pyrrolidine-1-carbonyl)-1,8-Naphthyridin -4(1H)-one (3a) \\ Yield $(85 \%)$; MP 202-204 ${ }^{\circ} \mathrm{C} ;{ }^{1} \mathrm{H}$ NMR $\left(\mathrm{CDCl}_{3}\right) \delta 8.8$ (s, 1H, Ar H), 8.6 (d, 1H, Ar), 7.2 (d, 1H, Ar, J=8.12), 4.5 (m, 2H, $\left.\mathrm{CH}_{2}\right), 3.3(\mathrm{t}, 4 \mathrm{H}$, pyrrolidine, $J=6.92), 1.59(\mathrm{t}, 4 \mathrm{H}$, pyrrolidine, $J=7.16)$; IR ( $\mathrm{KBr}$ pellet, $\mathrm{cm}^{-1}$ ) $1612 \mathrm{~cm}^{-1}$ confirms the presence of $\mathrm{C}=\mathrm{O}$ group and IR band in the region $1250 \mathrm{~cm}^{-1}$ confirms the $\mathrm{C}-\mathrm{N}$ stretching band.}

1-Ethyl-N,7 methyl-4-oxo-1,4-dihydro-1,8-Naphthyridine-3carboxamide (3b)

Yield $(45 \%) ;$ MP $218-219^{\circ} \mathrm{C} ;{ }^{1} \mathrm{H}$ NMR $\left(\mathrm{CDCl}_{3}\right) \delta 8.91$

(s, 1H, Ar), 8.6 (d, 2H, $\left.\mathrm{CH}_{2}, \mathrm{Ar}\right), 7.29$ (d, 2H, Ar, J=8.16), 4.54 (d, $2 \mathrm{H}, \mathrm{CH}_{2}$ ), 3.01 (s, 3H, methylamine), 2.61 (s, 3H), 1.5 (s, 3H) IR $\left(\mathrm{KBr}\right.$ pellet, $\left.\mathrm{cm}^{-1}\right) 1348 \mathrm{~cm}^{-1}$ confirms the presence of $\mathrm{C}-\mathrm{NH}$ group. IR ( $\mathrm{KBr}$ pellet, $\mathrm{cm}^{-1}$ ) $1600 \mathrm{~cm}^{-1}$ confirms the presence of $\mathrm{C}=\mathrm{O}$ bond.

N-(2,4-dimethylphenyl)-1-ethyl-7-methyl-4-oxo- 1,4-dihydro1,8-Naphthyridine-3 carboxamide (3c)

Yield $(72 \%) ; \operatorname{MP} 212-214^{\circ} \mathrm{C} ;{ }^{1} \mathrm{H} \mathrm{NMR}\left(\mathrm{CDCl}_{3}\right) \delta 9.0(\mathrm{~s}$, $1 \mathrm{H}, \mathrm{Ar}), 8.70$ (d, 2H, Ar, J=8.16), 8.18 (d, 1H, Ar, J =7.96), 7.3 (d, $1 \mathrm{H}, \mathrm{Ar}), 7.0$ (d, 1H, Ar), 4.56-4.61 (m, 2H, $\left.\mathrm{CH}_{2}\right), 2.71(\mathrm{~s}, 3 \mathrm{H}$, $\left.\mathrm{CH}_{3}\right), 2.44\left(\mathrm{~s}, 3 \mathrm{H}, \mathrm{CH}_{3}\right), 2.3\left(\mathrm{~s}, 3 \mathrm{H}, \mathrm{CH}_{3}\right), 1.5(\mathrm{~m}, 3 \mathrm{H})$; IR band at $1608 \mathrm{~cm}^{-1}$ confirms the presence of $\mathrm{C}=\mathrm{O}$ group and the stretching at $1363 \mathrm{~cm}^{-1}$ shows the presence of $\mathrm{C}-\mathrm{N}$ group

\section{1-Ethyl-7-methyl-3-(morpholine-4-carbonyl)-1,8-naphthyridin -4(1H)-one (3d)}

Yield $53 \%$; MP $185-187^{\circ} \mathrm{C} ;{ }^{1} \mathrm{H}$ NMR $\left(\mathrm{CDCl}_{3}\right) \delta 8.0(\mathrm{~s}$, $1 \mathrm{H}, \mathrm{Ar}), 7.5$ ( d, 2H, Ar, J=8.12), 3.67 3.2-3.8 (m, $8 \mathrm{H}$, morpholine), 2.55 ( $\left.\mathrm{s}, 3 \mathrm{H}, \mathrm{CH}_{3}\right), 1.2-1.4\left(\mathrm{~m}, 3 \mathrm{H}, \mathrm{CH}_{3}\right)$; IR band in the region $1608 \mathrm{~cm}^{-1}$ which confirms the presence of $\mathrm{C}=\mathrm{O}$ bond

\footnotetext{
1-Ethyl-7-methyl-3-(piperidine-1-carbonyl)-1,8-naphthyridine4(1H)-one (3e)

Yield 30\%; MP $173-175^{\circ} \mathrm{C} ;{ }^{1} \mathrm{H}$ NMR $\left(\mathrm{CDCl}_{3}\right) \delta 8.6(\mathrm{~d}$, $2 \mathrm{H}, \mathrm{Ar}, \mathrm{J}=8.08), 8.07$ (s, 1H, Ar), 7.2 (d, 2H, $\left.\mathrm{CH}_{2}, \mathrm{Ar}, J=8.12\right)$, 4.42-4.47 (m, 2H, $\left.\mathrm{CH}_{2}\right), 1.55(\mathrm{~s}, 2 \mathrm{H}$, piperidine), $1.50(\mathrm{~s}, 4 \mathrm{H}$, piperidine), $3.4(\mathrm{~s}, 2 \mathrm{H}$, piperidine), $3.3(\mathrm{~s}, 2 \mathrm{H}), 2.7(\mathrm{~s}, 3 \mathrm{H}), 1.3(\mathrm{~m}$, $3 \mathrm{H}, \mathrm{CH}_{3}, J_{l}=7.08, J_{2}=7.24$ ) IR band in the region $1608 \mathrm{~cm}^{-1}$ which confirms the presence of $\mathrm{C}=\mathrm{O}$ bond.
} 


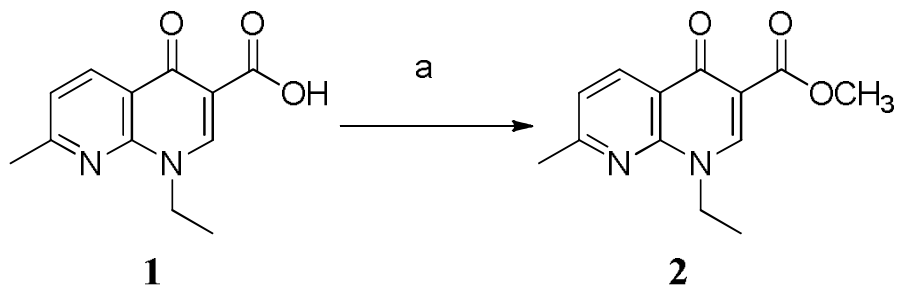

Scheme. 1: Synthesis of ester of nalidixic acid, reagents and conditions (a) Methanol, $\mathrm{SOCl}_{2}$, reflux, $1 \mathrm{~h}$.

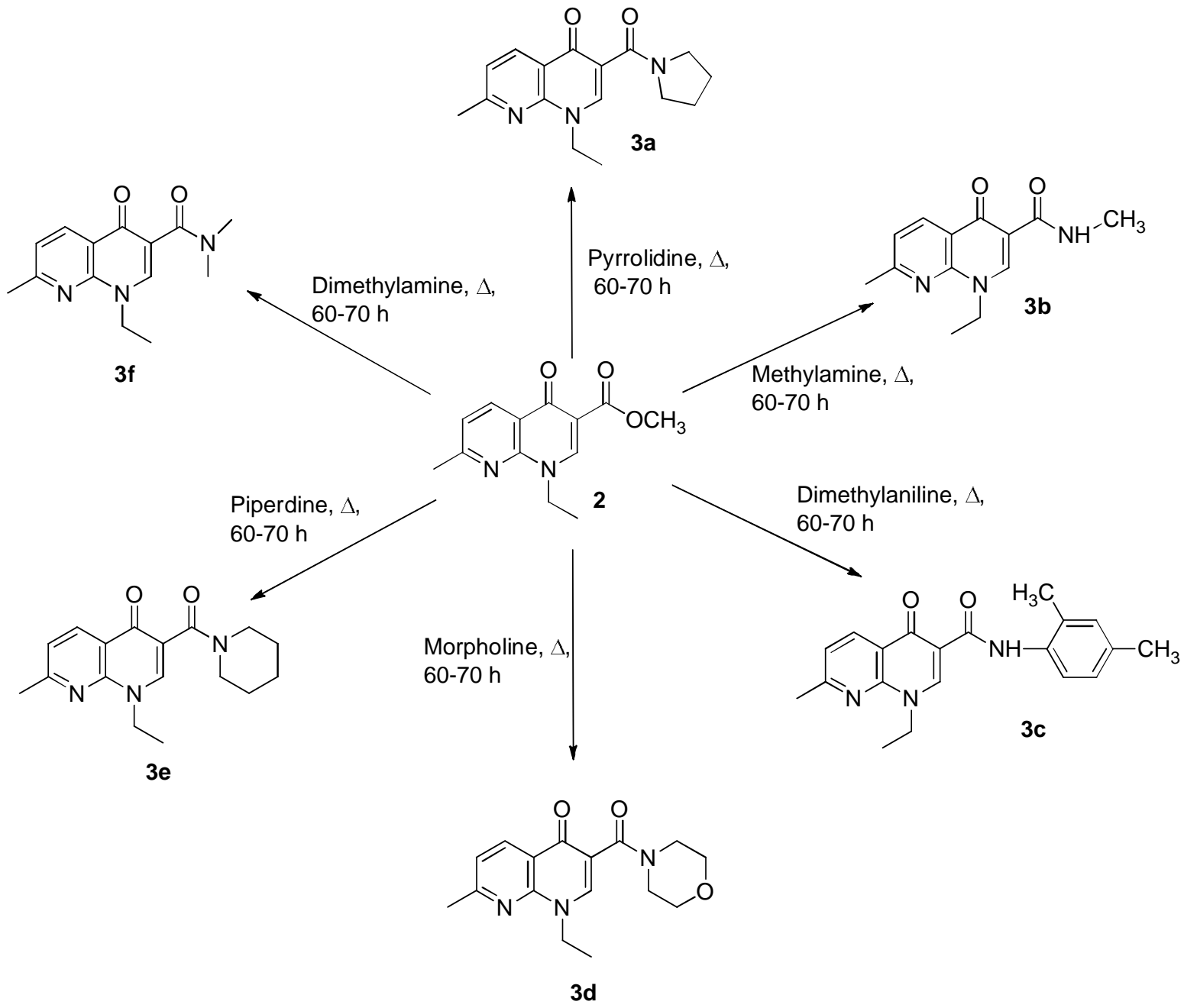

Scheme. 2. Synthesis of various derivatives (3a-3f) of nalidixic acid using various amines.

\section{1-Ethyl-N,7 dimethyl-4-oxo-1,4-dihydro-1,8-naphthyridine-3-} carboxamide (3f)

Yield 82\%; MP 206-208 ${ }^{\circ} \mathrm{C} ;{ }^{1} \mathrm{H}$ NMR $\left(\mathrm{CDCl}_{3}\right) \delta 8.8(\mathrm{~s}$, $1 \mathrm{H}, \mathrm{Ar}), 8.59$ (d, 1H, NH), 7.3 (d, 2H, Ar, J=7.36), 4.5 (d, 2H, $\left.\mathrm{CH}_{2}, J=6.24\right), 2.67$ (s, 3H, $\left.\mathrm{CH}_{3}\right), 1.47\left(\mathrm{t}, 3 \mathrm{H}, \mathrm{CH}_{3}\right)$; The IR $(\mathrm{KBr}$ pellet, $\mathrm{cm}^{-1}$ ) $1655 \mathrm{~cm}^{-1}$ shows the presence of $\mathrm{C}=\mathrm{O}$ group

\section{Antimicrobial Screening}

The synthesised compounds were screened for antibacterial activity against Gram (-) bacteria Pseudomonas aeruginosa (MTCC 424), E. coli. (MTCC 40), Gram (+) bacteria Staphylococcus aureus (MTCC 87), and Bacillus subtilis (MTCC 121) using agar dilution method and cup plate method.

\section{Agar dilution method}

Reference preparations of (3a-3f) were prepared in diluent DMSO (Dimethyl Sulphoxide) at $10 \mathrm{X}$ concentrations, and covered a full range of 30-200 $\mu \mathrm{g} \mathrm{m} \mathrm{m}^{-1}$. This method was convenient and economical on pipette use. Bacto agar was used as a medium for bacterial screening.

The compounds (3a-3f) were incorporated into liquefied agar medium at $45-50{ }^{\circ} \mathrm{C}$, mixed and poured in petridishes and allowed to solidify. A series of petriplates were prepared with increasing concentrations of the drug. With the help of inoculating applicator, as many as 4 different strains were spot inoculated on each plate. After overnight incubation, minimum inhibitory concentration (MIC) end point was determined by placing plate 
against a dark background and observing the lowest concentration of derivatives inhibiting visible growth (Grover et al., 2006). The MIC of each derivative was recorded in $\mu \mathrm{g} \mathrm{ml}^{-1}$. Wherever two or more colonies persisted beyond the end point or growth was present in higher concentration and not in lower concentration, the test was repeated.

\section{Cup plate diffusion / Punch well method}

In this technique petri dishes of agar medium plate were prepared by pouring melted agar inoculated with a variety of microorganisms. After the agar settled, cups were made in the agar petridishes. Test solutions were prepared using the following concentrations based on results obtained in agar dilution method.

Compound 3a in concentrations of 20, 40, 80, $100 \mu \mathrm{g} \mathrm{ml}^{-}$ ${ }^{1}, \mathbf{3 b}$ in concentrations of 40, 80, 100, $200 \mu \mathrm{g} \mathrm{ml} \mathrm{m}^{-1}, \mathbf{3 c}$ in concentrations of $80,100,200 \mu \mathrm{g} \mathrm{ml}^{-1}$ and $\mathbf{3 d}$ in concentrations of $20,40,80,100 \mu \mathrm{g} \mathrm{ml}^{-1}$ were made.

\section{Inoculum preparation}

Nutrient agar was applied for growing and diluting the suspensions. Bacterial strains were grown to exponential phase in nutrient agar at $37^{\circ} \mathrm{C}$ for $18 \mathrm{~h}$.

\section{Preparation of test solution}

Each test compound was dissolved in DMSO to get a concentration of $100 \mu \mathrm{g} \mathrm{ml}^{-1}$ and $200 \mu \mathrm{g} \mathrm{ml}^{-1}$.

\section{Procedure}

Agar media was made by dissolving 28 gm of bacto agar in $1000 \mathrm{ml}$ of purified water and it was kept in autoclave for sterilization. After sterilization, this agar media was inoculated with four different strains of bacteria. This media was poured in petridishes. After the agar settled, cups were made in the agar petridishes. To these cups, drugs in different concentrations were added and the plates were kept overnight undisturbed. Then the zone of inhibition was measured. All the compounds (3a-3f) were compared with nalidixic acid for antibacterial activity.

\section{Test solution}

100 and $200 \mu \mathrm{g} / \mathrm{ml}$ of Nalidixic acid and synthesized compounds (3a-3f) were prepared in suitable solvent.

\section{Molecular docking}

Molecular docking is a vital tool applied for carrying out structure based drug design approach to dock small ligands in the active site of target receptor proteins (Shoichet et al., 2002). The docked ligands can be ranked on the basis of their binding affinity, and docking pose in the target site.

The comparison between the docked ligands and the reference ligand on the basis of their docking score can be made easily. The structure of DNA Gyrase B (PDB ID code: 4GEE) (Tari et al., 2013) co-crystallized with novel pyrrolopyrimidine inhibitor was taken from the RSC-PDB (Research Collaboratory for Structural Bioinformatics-Protein Data Bank) depository (http://www.rcsb.org/). The ligands were drawn in Chem Draw Ultra 12.0 followed by MM2 minimization of ligands (using ChemBio3D Ultra 12.0) by keeping a check on the connection error in the bonds. Protein and Grid preparation was done using Autodock Vina 1.1.2 (Trott et al., 2010) and was used to perform molecular docking.

\section{RESULTS AND DISCUSSION}

The nalidixic acid was taken as a starting material for the synthesis for various derivatives (3a-3f) (Scheme 1,2). The obtained compounds were tested for antibacterial activity. The synthesized compounds showed marked inhibitory activity against $P$. aeruginosa, $S$. aureus and E.coli with agar dilution method. Only those strains which were found to be susceptible to the test derivatives, have been utilized for cup plate diffusion method and results are listed in Table 1-3

Table 1: Antimicrobial results of synthesised compounds $\mathbf{3 a}, \mathbf{3 b}$ using agar dilution method.

\begin{tabular}{|c|c|c|c|c|c|c|c|c|c|}
\hline \multirow{3}{*}{ Strain Used } & \multicolumn{4}{|c|}{ Derivative 3a } & \multirow{3}{*}{$\frac{\text { Nalidixic acid }}{20}$} & \multicolumn{4}{|c|}{ Derivative 3b } \\
\hline & \multicolumn{4}{|c|}{ Concentration in $\mu \mathrm{g} \mathrm{ml}^{-1}$} & & \multicolumn{4}{|c|}{ Concentration in $\mu \mathrm{g} \mathrm{ml}^{-1}$} \\
\hline & 20 & 40 & 80 & 100 & & 20 & 40 & 80 & 100 \\
\hline P.aeruginosa & - & - & + & + & - & - & - & - & - \\
\hline S.aureus & - & + & + & + & + & - & + & + & + \\
\hline B.subtilis & - & + & + & + & + & - & + & + & + \\
\hline E.coli & + & + & + & + & + & + & + & + & + \\
\hline
\end{tabular}

Table 2: Antimicrobial results of synthesised compounds $\mathbf{3 c}, \mathbf{3 d}$ using agar dilution method.

\begin{tabular}{|c|c|c|c|c|c|c|c|c|c|}
\hline \multirow{3}{*}{ Strain Used } & \multicolumn{4}{|c|}{ Derivative 3c } & \multirow{3}{*}{$\frac{\text { Nalidixic acid }}{20}$} & \multicolumn{4}{|c|}{\begin{tabular}{|l} 
Derivative 3d \\
\end{tabular}} \\
\hline & \multicolumn{4}{|c|}{ Concentration in $\mu \mathrm{g} \mathrm{ml}^{-1}$} & & \multicolumn{4}{|c|}{ Concentration in $\mu \mathrm{g} \mathrm{ml}^{-1}$} \\
\hline & 20 & 40 & 80 & 100 & & 20 & 40 & 80 & 100 \\
\hline P.aeruginosa & - & - & - & - & - & - & - & - & - \\
\hline S.aureus & - & + & + & + & - & - & + & + & + \\
\hline B.subtilis & - & + & + & + & + & - & + & + & + \\
\hline E.coli & + & + & + & + & + & + & + & + & + \\
\hline
\end{tabular}

$(-)$ Represents no inhibition of growth/resistant; $(+)$ represents inhibition of growth/susceptible. 
Table 3: Punch well/Cup plate diffusion method results of compounds (3a-3f).

\begin{tabular}{|c|c|c|c|c|c|c|c|c|c|c|c|c|}
\hline \multirow{3}{*}{ Microorganism } & \multicolumn{12}{|c|}{ Inhibition zone (in mm) } \\
\hline & \multirow{2}{*}{$\begin{array}{c}3 a \\
\text { Conc. } \\
\mu \mathrm{g} / \mathrm{ml}\end{array}$} & \multicolumn{3}{|c|}{$3 \mathbf{b}$} & \multicolumn{2}{|l|}{$3 c$} & \multicolumn{2}{|c|}{ 3d } & \multicolumn{2}{|l|}{$3 \mathbf{e}$} & \multicolumn{2}{|c|}{ Nalidixic acid } \\
\hline & & $\mathbf{m m}$ & $\begin{array}{c}\text { Conc. } \mu \\
\mathrm{g} / \mathrm{ml}\end{array}$ & $\mathbf{m m}$ & $\begin{array}{l}\text { Conc. } \\
\mu \mathrm{g} / \mathrm{ml}\end{array}$ & Mm & $\begin{array}{l}\text { Conc. } \\
\mu \mathrm{g} / \mathrm{ml}\end{array}$ & $\mathbf{m m}$ & $\begin{array}{l}\text { Conc. } \\
\mu \mathrm{g} / \mathrm{ml}\end{array}$ & $\mathbf{m m}$ & $\begin{array}{l}\text { Conc. } \\
\mu \mathrm{g} / \mathrm{ml}\end{array}$ & $\mathbf{m m}$ \\
\hline \multirow{4}{*}{ Bacillus subtilis } & 20 & - & 30 & - & 50 & 12 & 20 & - & 20 & - & \multirow{4}{*}{30} & \multirow{4}{*}{20} \\
\hline & 40 & 18 & 50 & 16 & 100 & 14 & 40 & 17 & 40 & 19 & & \\
\hline & 80 & 22 & 100 & 20 & 150 & 15 & 80 & 21 & 60 & 24 & & \\
\hline & 100 & 26 & 200 & 22 & 200 & 21 & 100 & 25 & 80 & 27 & & \\
\hline \multirow{4}{*}{$\begin{array}{c}\text { Staphylococcus } \\
\text { aureus }\end{array}$} & 20 & - & 30 & 9 & 50 & - & 20 & - & 20 & - & \multirow{4}{*}{30} & \multirow{4}{*}{-} \\
\hline & 40 & 18 & 50 & 6 & 100 & - & 40 & 15 & 40 & 20 & & \\
\hline & 80 & 21 & 100 & 8 & 150 & - & 80 & 22 & 60 & 23 & & \\
\hline & 100 & 23 & 200 & 14 & 200 & - & 100 & 25 & 80 & 27 & & \\
\hline \multirow{4}{*}{ Escherichia coli } & 20 & - & 30 & - & 50 & - & 20 & - & 20 & - & \multirow{4}{*}{30} & \multirow{4}{*}{18} \\
\hline & 40 & 12 & 50 & 10 & 100 & - & 40 & 20 & 40 & 27 & & \\
\hline & 80 & 23 & 100 & 16 & 150 & 19 & 80 & 27 & 60 & 29 & & \\
\hline & 100 & 30 & 200 & 19 & 200 & 22 & 100 & 32 & 80 & 34 & & \\
\hline \multirow{3}{*}{$\begin{array}{c}\text { Pseudomonas } \\
\text { aeruginosa }\end{array}$} & 20 & 10 & 30 & - & 50 & - & 20 & - & 20 & - & \multirow{3}{*}{30} & \multirow{3}{*}{-} \\
\hline & 40 & 10 & 50 & - & 100 & - & 40 & - & 40 & - & & \\
\hline & 80 & 10 & 100 & - & 150 & - & 80 & - & 60 & - & & \\
\hline
\end{tabular}

(-) represents no inhibition of growth/ Resistant.

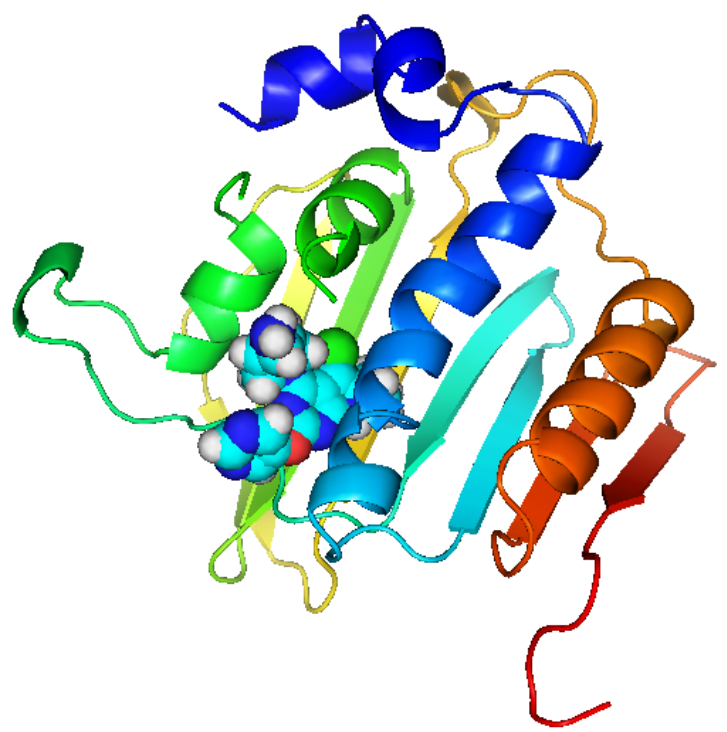

Fig. 1: Structure of bacterial GyrB enzyme (PDB ID: 4GEE).
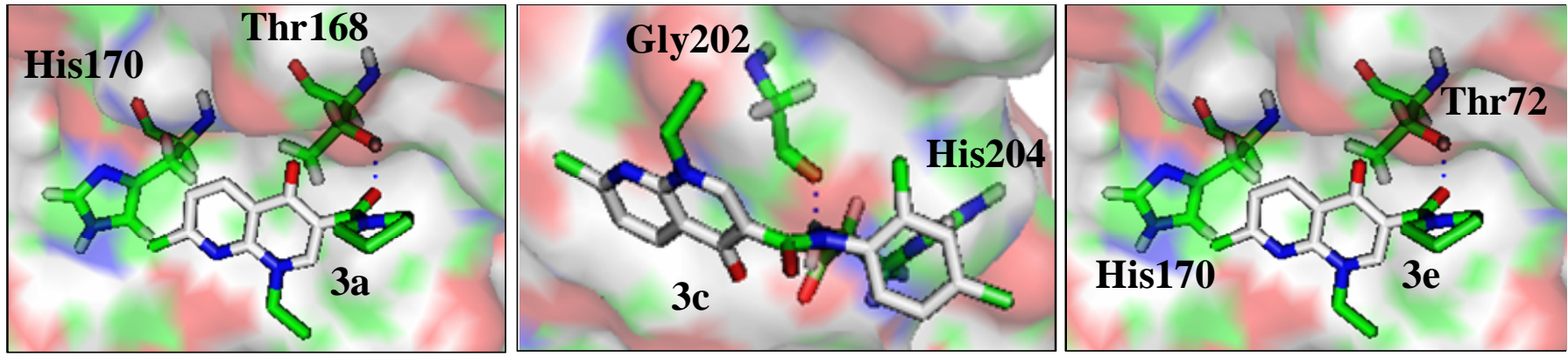

Fig. 2: Docked pose of 3a, 3c, 3e in the binding pocket of GyrB (PDB: 4GEE). Dashed lines represents hydrogen bonding interaction.

\section{Molecular Docking studies}

Molecular docking studies were carried out to understand the binding profile of synthesized naphthyridrine derivatives (3a3f) and to support the in vitro antimicrobial activity. Automated docking was used to determine the orientation of inhibitors bound in the active site of DNA-Gyrase B (PDB ID: 4GEE) (Tari et al., 2013). A Lamarckian genetic algorithm method, implemented in the program AutoDock Vina 1.1.2, was employed. The 3Dstructure of E. Faecalis isolated GyrB enzyme is provided in Figure 1. The docking of series of ligands (3a-3f) indicated that all the synthesized compounds have potential of binding with one or the other amino acids in the active pockets as evident from the docking scores provided in Table 4 . The 2D structures of ligands were drawn and 3D coordinates were developed using 
ChemBio3D Ultra 12.0 after performing MM2 minimization. The protein structure file (PDB ID: 4GEE) taken from Protein Data Bank (www.rcsb.org/pdb) and was prepared for docking by removal of water molecules, adding polar hydrogens and by adding Kollman charges to the structure file. In silico prediction of amino acids involved in the active site pocket of protein which are involved in binding with the ligands are obtained from the cocrystallized endogenous ligand from the PDB file. Ligand preparation is done by adding Gasteiger charges, different conformation of ligands were built by allowing rotation of all torsions during docking.

Table 4: Docking score of synthesized 1,8- Naphthyridine derivatives (3a-3f) in GyrB active site pocket.

\begin{tabular}{cc}
\hline Compound & Docking score (kcal/mol) \\
\hline Co-crystallized ligand & -6.5 \\
Nalidixic acid & -6.0 \\
3a & -6.5 \\
3b & -6.2 \\
3c & -7.2 \\
3d & -6.2 \\
3e & -6.6 \\
3f & -5.8 \\
\hline
\end{tabular}

Theoretically all the synthesized compounds showed moderate to good binding scores ranging from -5.8 to -7.2 $\mathrm{kcal} / \mathrm{mol}$. Out of the six compounds, four compounds are showing comparative docking score in comparison to co-crystallized ligand (pyrrolopyrimidine), however most of the ligands are showing better docking scores in comparison to nalidixic acid which is used as a reference for biological interpretations. Molecular docking studies revealed that compounds $(\mathbf{3 a}, \mathbf{3 c}, \mathbf{3 e})$ are showing good binding scores, however among these compounds $\mathbf{3 c}$ shows highest docking score of $-7.2 \mathrm{kcal} / \mathrm{mol}$ (Table 4). In $\mathbf{3 c}$, the $\mathrm{NH}$ of amide group forms intermolecular hydrogen bond with Gly202 having hydrogen bond distance of $2.1 \AA$. Though this compound is also stabilized by T-type $\pi-\pi$ aromatic interaction of dimethylphenyl ring with His204 amino acid residue (Figure 2). In case of compound $\mathbf{3 a}$, the hydrogen bonding interaction is again found of the order of $2.1 \AA$, with slight stabilization provided by His170. Compound 3e, also show similar type of interaction with more parallel $\pi$-type aromatic stabilization. The present data supports the in vitro results which suggest that compound 3a (docking score $=-6.5 \mathrm{kcal} / \mathrm{mol}$ ) and 3e (docking score $=-6.7$ $\mathrm{kcal} / \mathrm{mol}$ ) is showing good antimicrobial activities which is better in comparison to nalidixic acid which is showing a docking score of $-6.0 \mathrm{kcal} / \mathrm{mol}$. Hence, it can be expected that the observed activity is coming from the inhibition of enzyme GyrB, which cause negative supercoiling of DNA. Thus, these probable enzyme inhibitors hampers the replication of bacterial DNA and exhibit antibacterial activity.

\section{Toxicity assay of biologically active compounds}

In silico Ames mutagenicity profiles of the compounds (3a-3f) showing anti-microbial activity were assessed using the TOPKAT toxicity prediction tool (http://accelrys.com/products/ discovery-studio/qsar-admet-and-predictive-toxicology.html). TOPKAT computes the toxicity of query compound through Quantitative Structure Toxicity Relationship (QSTR) equation. QSTR generates a score in the form of probability values. The toxicity of the compound for the biological system may depend upon these probability values. A probability value in the range of $0.0-0.3$, are considered as low, and the structures having TOPKAT computed probability values falling in this range are most likely not to produce a toxic response effect in the biological system while values above 0.7 are considered high and are more likely to possess a toxic response. We analyzed our compounds against the Ames mutagenicity model (Table 5) showing that the biologically active compounds have almost zero computed probability values which are not likely to produce positive response in the experimental assay and offer negative contribution to increase in the probability of chosen properties. The results show that computed values for Ames mutagenicity test fall in the range $0.000-0.124$, which ruled out chances of showing mutagenicity by compounds under investigation. Thus, the TOPKAT results clearly indicate that compounds belonging to 1,8-Napthahydrine class are promising molecules with safer toxicity profiles.

Table 5: Computed probability and discriminant scores of biologically active compounds on Ames mutagenicity models.

\begin{tabular}{ccc}
\hline Compound & \multicolumn{2}{c}{ Ames Mutagenicity (v3.1) } \\
\hline & Computed Probability & Discriminant Score \\
\hline 3a & 0.000 & 12.415 \\
3b & 0.000 & 10.533 \\
3c & 0.000 & -11.830 \\
3d & 0.124 & 19.745 \\
3e & 0.000 & 02.587 \\
3f & 0.000 & 12.442 \\
\hline
\end{tabular}

\section{CONCLUSIONS}

A series of 1,8-Naphthyridine derivatives were synthesized from nalidixic acid with various substituted amines. The yield of the synthesized compounds was found to be in range from $30-85 \%$. All the newly synthesized compounds were characterized on the basis of their physical and spectral data. The FT-IR, 1H NMR and Mass spectral data of the representative compounds were analyzed. Synthesized compounds were tested for antimicrobial activity. All the synthesized compounds showed moderate to good antibacterial activities. The results revealed that the activity of compounds against Gram positive bacteria was higher than that of the Gram negative bacteria. In the present study, acid group of nalidixic acid has been replaced with various amines and synthesized compounds were screened for antibacterial activity.

Synthesized compounds $\mathbf{3 a}, \mathbf{3 b}$ and $\mathbf{3 d}$ exhibited inhibitory activity against Pseudomonas aeruginosa, which was resistant to pure nalidixic acid. Similarly, derivative 3a and 3d showed inhibitory activity against $S$. aureus, which was also resistant to pure nalidixic acid. However, no inhibitory activity was observed with 3c. Molecular docking studies revealed that compounds $\mathbf{3 a}$ and $\mathbf{3 e}$ is showing sufficiently better binding scores 
of $-6.5 \mathrm{kcal} / \mathrm{mol}$ and $-6.6 \mathrm{kcal} / \mathrm{mol}$ respectively in comparison to nalidixic acid $(-6.0 \mathrm{kcal} / \mathrm{mol})$ which is well reflected in the experimental studies as well. These compounds mainly show hydrogen bonding interaction with $\mathrm{C}=\mathrm{O}$ linkage which act as hydrogen bond acceptor and stabilize the docked conformation. These compounds also have potential to show sandwich type $\pi$ stacking interactions with aromatic rings of napthahydrine framework.

\section{ACKNOWLEDGEMENT}

The authors are thankful to SAIF, Panjab University, Chandigarh, for providing spectral data of synthesized compounds. Authors are also highly thankful to NIPER, SAS-Nagar, for providing help in performing computational analysis.

\section{REFERENCES}

Aarons SJ, Sutherland IW, Chakrabarty AM, Gallagher MP. A novel gene, algK, from the alginate biosynthetic cluster of Pseudomonas aeruginosa. Microbiology 1997; 143: 641-652.

Andriote VT. The 1998 Garrod lecture. Current and future antifungal therapy: new targets for antifungal agents. J Antimicrob Chemother 1999; 44: 151-162.

Arora P, Narang R, Bhatia S, Nayak SK, Singh SK, Narasimhan B. Synthesis, molecular docking and QSAR studies of 2, 4disubstituted thiazoles as antimicrobial agents. J App Pharm Sci 2015; 5: $28-42$.

Ashok, R. In: Antimicrobials in Laboratory Medicine, B. I. Churchill, Livingstone, 2000; 62-70.

Available at: http://accelrys.com/products/discoverystudio/qsar-admet-and-predictive-toxicology.html

Available at: http://www.cdc.gov/drugresistance/threat-report-

2013/

Available at: http://www.rcsb.org/

Black JG. Microbiology: Principles and Applications. PrenticeHall, Englewood Cliffs, New Jersey 1993; 360.

Dianzani C, Collino M, Gallicchio M, Braccio MD, Roma G, Fantozzi R. Effects of anti-inflammatory [1, 2, 4]triazolo[4, 3-a] $[1,8]$ naphthyridine derivatives on human stimulated PMN and endothelial cells: an in vitro study. J Inflam (Lond). 2006; 3: 4.

Ferrarini PL, Betti L, Cavallini T, Giannaccini G, Lucacchini A, Manera C, Martinelli A. Study on affinity profile toward native human and bovine adenosine receptors of a series of 1,8-naphthyridine derivatives. J Med Chem 2004; 47: 3019-3031.

Ferrarini PL, Calderone V, Cavallini T, Manera C, Saccomanni G, Pani L, Ruiu S, Gessa GL. Synthesis and biological evaluation of 1,8-naphthyridin-4(1H)-on-3 carboxamide derivatives as new ligands of cannabinoid receptors. Bioorg Med Chem 2004; 12: 19211933.

Ferrarini PL, Manera C, Mori C, Badawneh M, Saccomanni G. Synthesis and evaluation of antimycobacterial activity of 4-phenyl-1,8naphthyridine derivatives, Il Farmaco 1998; 53: 741-746.

Grover G, Kini SG. Synthesis and evaluation of new quinazolone derivatives of nalidixic acid as potential antibacterial and antifungal agents. Eur J Med Chem 2006; 41: 256-262.
Lv K, Liu ML, Feng LS, Sun LY, Sun YX, Wei ZQ, Guo HQ. Synthesis and antibacterial activity of naphthyridone derivatives containing mono/difluoro-methyloxime pyrrolidine scaffolds. Eur J Med Chem 2012, 47: 619-625.

Manera C, Betti L, Cavallini T, Giannaccini G, Martinelli A, Ortore G, Saccomanni G, Trincavelli L, Tuccinardia T, Ferrarini PL. 1,8Naphthyridin-4-one derivatives as new ligands of A2A adenosine receptors, Bioorg Med Chem Lett, 2005; 15:4604-4610.

Mekheimer RA, Hameed, AMA, Sadek KU. 1,8-Naphthyridines II: Synthesis of novel polyfunctionally substituted 1,8-Naphthyridinones and their degradation to 6-amino pyridones. ARKIVOC 2007; 8: 269-281.

Narasimhan B, Ohlan S, Ohlan R, Judge V, Narang R. Hansch analysis of veratric acid derivatives as antimicrobial agents. Eur $\mathbf{J}$ Med Chem, 2009; 44:689-700.

Ortore G, Saccomanni G, Tuccinardi T. Study on affinity profile toward native human and bovine adenosine receptors of a Series of 1,8Naphthyridine derivatives. J Med Chem 2004; 47: 3019-3031.

Pelczar MJ, Chan ECS, Krieg NR. Microbiology. Tata Mcgraw-Hill Publishing Company Ltd., New Delhi 2005, 3-10, 490.

Perez KK, Olsen RJ, Musick WL, Cernoch PL, Davis JR, Peterson LE, Musser JM. Integrating rapid diagnostics and antimicrobial stewardship improves outcomes in patients with antibiotic resistant Gram negative bacteremia. J Infect 2014; 69: 216-225.

Silverman RB. Organic Chemistry of Drug Design and Drug Action, Academic Press, San Diego, 1992: 7-86.

Shoichet BK, McGovern, SL, Wei B, Irwin JJ. Lead discovery using molecular docking. Curr Opin Chem Biol 2002; 6: 439-446.

Singh S, Wanjari PJ, Bhatia S, Sonwane VC, Chakraborti AK, Bharatam PV. Design, synthesis, biological evaluation and toxicity studies of N,N-disubstituted biguanides as quorum sensing inhibitors. Med Chem Res 2015; 5: 28-42.

Smith J. The mode of action of 4-quinolones and possible mechanisms of resistance. J Antimicrob Chemother 1986; 18: (Supplement D), 21-29.

Tari LW, Trzoss M, Bensen DC, Li X, Chen Z, Lam T, Zhang J, Creighton CJ, Cunningham ML, Kwan B. Pyrrolopyrimidine inhibitors of DNA gyrase B (GyrB) and topoisomerase IV (ParE). Part I: Structure guided discovery and optimization of dual targeting agents with potent, broad-spectrum enzymatic activity. Bioorg Med Chem Lett 2013; 23: 1529-1536.

Thompson LA, Ellman JA. Synthesis and Applications of Small Molecule Libraries. Chem Rev 1996; 96: 555-600.

Trott O, Olson AJ. AutoDock Vina: improving the speed and accuracy of docking with a new scoring function, efficient optimization and multithreading. J Comput Chem 2010; 31:455-461.

\section{How to cite this article:}

Sakshi Sachdeva, Sonam Bhatia, Amit Mittal and Manish Sinha. Synthesis, Evaluation and in silico studies of 1,8-Naphthyridine derivatives against antimicrobial activity. J App Pharm Sci, 2015; 5 (07): 053-059. 